\title{
Economic values of production and functional traits, including residual feed intake, in Finnish milk production
}

\author{
P. Hietala, ${ }^{* 1}$ M. Wolfová, $†$ J. Wolf, $†$ J. Kantanen, $\neq$ and J. Juga* \\ *Department of Agricultural Sciences, University of Helsinki, FI-00014 Helsinki, Finland \\ †Institute of Animal Science, Přátelství 815, CZ-10400 Prague Uhřiněves, Czech Republic \\ łBiotechnology and Food Research, MTT Agrifood Research Finland, FI-31600 Jokioinen, Finland
}

\begin{abstract}
Improving the feed efficiency of dairy cattle has a substantial effect on the economic efficiency and on the reduction of harmful environmental effects of dairy production through lower feeding costs and emissions from dairy farming. To assess the economic importance of feed efficiency in the breeding goal for dairy cattle, the economic values for the current breeding goal traits and the additional feed efficiency traits for Finnish Ayrshire cattle under production circumstances in 2011 were determined. The derivation of economic values was based on a bioeconomic model in which the profit of the production system was calculated, using the generated steady state herd structure. Considering beef production from dairy farms, 2 marketing strategies for surplus calves were investigated: (A) surplus calves were sold at a young age and (B) surplus calves were fattened on dairy farms. Both marketing strategies were unprofitable when subsidies were not included in the revenues. When subsidies were taken into account, a positive profitability was observed in both marketing strategies. The marginal economic values for residual feed intake (RFI) of breeding heifers and cows were -25.5 and $-55.8 € / \mathrm{kg}$ of dry matter per day per cow and year, respectively. The marginal economic value for RFI of animals in fattening was $-29.5 € / \mathrm{kg}$ of dry matter per day per cow and year. To compare the economic importance among traits, the standardized economic weight of each trait was calculated as the product of the marginal economic value and the genetic standard deviation; the standardized economic weight expressed as a percentage of the sum of all standardized economic weights was called relative economic weight. When not accounting for subsidies, the highest relative economic weight was found for 305-d milk yield (34\% in strategy A and $29 \%$ in strategy B), which was followed by protein percentage (13\% in strategy $\mathrm{A}$ and $11 \%$ in strategy B). The third most important traits
\end{abstract}

Received May 31, 2013.

Accepted October 29, 2013.

${ }^{1}$ Corresponding author: pauliina.hietala@helsinki.fi were calving interval $(9 \%)$ and mature weight of cows (11\%) in strategy A and B, respectively. The sums of the relative economic weights over categories for RFI were 6 and $7 \%$ in strategy A and B, respectively. Under production conditions in 2011, the relative economic weights for the studied feed efficiency traits were low. However, it is possible that the relative importance of feed efficiency traits in the breeding goal will increase in the future due to increasing requirements to mitigate the environmental impact of milk production.

Key words: dairy cattle, economic value, feed efficiency, residual feed intake

\section{INTRODUCTION}

Milk production accounts for almost half of the total market-based return of agricultural production in Finland and is thus economically the most important branch in Finnish agriculture (MTTL, 2012). Therefore, the profitability of milk production plays an essential role in ensuring the economic sustainability of Finnish agriculture in the future. In 2011, there were 285,500 dairy cows in Finland (Matilda Agricultural Statistics, 2013), of which approximately 63\% were Finnish Ayrshire. Although the productivity of dairy farms has increased considerably over the last decade (MTTL, 2012), the low product prices together with the high production costs have resulted in income losses that have been compensated to farmers mainly through subsidies.

Selection for milk production traits has traditionally received the most emphasis in national breeding programs for dairy cattle in many countries. Recently, more attention has been paid to the genetic improvement in functional traits associated with a reduction of production costs (Miglior et al., 2005). Given that feed cost is a major single expense in dairy farming in Finland, improving feed efficiency of dairy cattle could have a substantial effect on the profitability of dairy production. Moreover, from an environmental point of view, the increased public concern for the environmental impact of livestock production produces a challenge for the dairy industry to mitigate the environmental 
impact of dairy farming. More efficient feed utilization in dairy cattle has been connected with a reduction in greenhouse gas emissions from milk production through lower methane and manure outputs of animals and resource use in the production of food (Yan et al., 2010; Thoma et al., 2013). So far, improvements in feed efficiency of dairy cows have been mainly achieved indirectly through improvement in milk production. This improved production efficiency is known as the "dilution of maintenance effect" (Bauman et al., 1985), wherein increased milk production results in decreased maintenance cost of animals per kilogram of milk. However, the benefits of improved milk production in terms of feed efficiency have not been straightforward. This is due to the fact that selection for milk production has been connected with increasing mature weight of cows, which, in turn, has increased energy requirements for maintenance (Yan et al., 1997).

A suggested option for achieving a direct genetic improvement in feed efficiency is selection for residual feed intake (RFI), which was initially proposed by Koch et al. (1963). Residual feed intake is defined as the difference between an animal's actual feed intake and its predicted feed intake, the prediction usually being estimated based on energy requirements for production, maintenance, and body condition change (Veerkamp et al., 1995). Therefore, an animal with low RFI is more feed efficient than an animal with high RFI when compared with the population mean. Due to the definition of RFI, the measure is independent of the production level and body size of the animal (Van Arendonk et al., 1991) and is also considered to assess the animal's metabolic efficiency (Williams et al., 2011). However, the calculation of RFI for dairy cows is complicated due to the dynamic changes occurring in BW and BCS during the lactation cycle (Williams et al., 2011). In addition, lack of a cost-efficient method for measuring RFI on commercial dairy farms has limited the inclusion of the trait in the breeding goal for dairy cattle. The recently estimated moderate accuracy (0.31-0.37) of the genomic breeding value for RFI in growing Holstein heifers (Pryce et al., 2012) refers to the fact that selection for RFI is likely to become more feasible due to the possibility of using genomic selection in the near future.

The Nordic total merit (NTM) index (Pedersen et al., 2008) has included both production and functional traits for several years, which is in line with the Nordic countries' breeding goals for dairy breeds. However, to date, no feed efficiency traits have been included in the NTM index. Considering the economic and environmental benefits of efficient feed utilization for dairy production, improving this trait should be considered for inclusion in the future breeding goals for Nordic dairy breeds. The first aim of this study was to derive the economic weights for traditional traits in the breeding goal and feed efficiency traits for Finnish Ayrshire dairy cattle under market conditions in 2011. The second aim was to compare the economic efficiency and economic values of traits in a dairy production system under different strategies for beef production from fattened surplus calves. Approximately $85 \%$ of Finnish beef production can be considered as a by-product of milk production.

\section{MATERIALS AND METHODS}

The economic weights for the traits currently included in the Nordic breeding goal and the additional feed efficiency traits for Finnish Ayrshire were calculated using the program EWDC (version 2.2.3) from the program package ECOWEIGHT (Wolf et al., 2012). The details of the bioeconomic model used in the program are described by Wolfová et al. (2007a,b) and, therefore, the applied model will be described only in general terms in the current paper. In the model, a deterministic approach with some stochastic elements was applied. Most of the traits were defined as population averages; however, variation in several traits was taken into account. For the traits milk fat and milk protein percentages and SCS, a normal distribution with a given mean and standard deviation was modeled. This approach allowed a correct calculation of the average milk price for the milk pricing system based on fat and protein differentials and on SCC.

The main parts of the model included (1) calculation of the steady-state herd structure for a given production system using dynamic modeling (Markov chain) and population parameters allowing 15 reproductive cycles for a cow; (2) calculation of the categories of progeny; (3) calculation of the growth patterns of animal groups as well as milk yield in individual lactations; (4) calculation of revenues and costs for each animal group and the total profit of production based on a function of biological, economic, and management parameters; and (5) calculation of economic values for traits. The input parameters used in the model were adapted from milk recording data, from the literature, and from average producer and purchase prices of agricultural products in Finland for the year 2011.

\section{Production System and Management Strategy}

The management of the production system, herd characteristics, and average production parameters represented the current situation on an average dairy farm in Finland. In the model, an indoor dairy farming system with loose housing of cows was assumed. In this system, all cows were artificially inseminated; a maxi- 
Table 1. Input parameters used for calculating the herd structure

\begin{tabular}{lrr}
\hline & \multicolumn{2}{c}{ Reproductive cycle } \\
\cline { 2 - 3 } Parameter & \multicolumn{2}{c}{$\geq 2$} \\
\hline Mortality rate of cows (\%) & 1.4 & 3.0 \\
Abortion rate of cows (\%) & 1.3 & 1.7 \\
Stillbirth rate after easy calving (\%) & 3.3 & 1.8 \\
Stillbirth rate after calving difficulty (\%) & 18.8 & 15.2 \\
Cows culled within reproductive cycle for health problems (\%) & 16.1 & 35.1 \\
Cows culled due to low milk production (\%) & 1.8 & 2.2 \\
Dystocia rate (\%) & 6.8 & 3.2 \\
Purebred female calf is born & 12.0 & 5.7 \\
Purebred male calf is born & 9.5 & 5.3 \\
Crossbred female calf is born & 18.1 & 11.3 \\
Crossbred male calf is born & $34,35,32$ \\
Conception rate of cows for first, second, and $\geq$ third insemination (\%) & $60,57,57$ \\
Conception rate of heifers for first, second, and $\geq$ third insemination (\%) & \multicolumn{2}{c}{3} \\
Culling rate of cows after dystocia (\%) & \multicolumn{2}{c}{2} \\
Decrease in conception rate after dystocia (\%) & \multicolumn{2}{c}{} \\
\hline
\end{tabular}

mum of 7 inseminations per cow and 6 inseminations per heifer during the mating period were allowed. Cows and heifers that did not conceive after the given number of inseminations were culled at the end of the lactation and at the end of the mating period, respectively. All replacement heifers were raised on the farm. A small proportion $(0.2 \%)$ of the bull calves was selected for replacement and sold to the AI breeding program at the age of $135 \mathrm{~d}$.

In Finland, most dairy farms sell surplus calves to specialized fattening farms at a young age. However, some dairy farms still fatten their own surplus calves and, therefore, the following 2 scenarios considering the marketing strategies for surplus calves were investigated: (A) surplus calves were sold to specialized fattening farms at the age of $20 \mathrm{~d}$ and (B) surplus calves were fattened on dairy farms where born. In marketing strategy $\mathrm{B}$, an intensive indoor fattening of animals slaughtered at a fixed slaughter weight was assigned. In addition, a situation where $10 \%$ of the cows were mated with Limousin bulls to produce crossbred calves for meat production was examined.

The structure of the dairy herd in its steady state was generated using a Markov chain approach as described by Wolfová et al. (2005a). The main input parameters used for calculating the herd structure are summarized in Table 1. The herd performance parameters, corresponding to the Finnish production system, were calculated from the field data of Finnish milk recorded herds collected between 2006 and 2011. The data was received from the breeding organization Faba (Hollola, Finland).

\section{Description of Traits}

Economic values were derived for 21 different traits, which can be assigned to 5 sets of traits.
Milk Production Traits. Milk production traits included 305-d milk yield, protein percentage, and fat percentage.

Growth Traits. Growth traits were birth weight, ADG in the rearing period, ADG in the fattening period, and mature weight of cows, defined as the average weight of cows after third calving.

Carcass Traits. Carcass traits included dressing percentage and average class of fleshiness and fat covering. The classifications of fleshiness and fat covering of carcasses were based on the European SEUROP classification system. For fleshiness, 5 main classes (E, U, R, $\mathrm{O}$, and $\mathrm{P}$ ) were assigned, with $\mathrm{E}$ representing the best class and $\mathrm{P}$ representing the worst class. In addition, $\mathrm{R}, \mathrm{O}$, and $\mathrm{P}$ classes were divided into 3 subclasses (e.g., $\mathrm{R}+, \mathrm{R}$, and $\mathrm{R}-$ ), producing overall 11 different classes for fleshiness. When calculating an economic value for fleshiness, the classes were transformed into numbers, so that numbers from 1 to 11 were inserted for classes from $\mathrm{E}$ to $\mathrm{P}$-. Fat covering of a carcass was classified into 5 grades, numbered from 1 to 5 , with 1 used for low fat covering and 5 for high fat covering.

Functional Traits. Functional traits were calving difficulty score, stillbirth, calf mortality in the rearing period, interval from first AI to conception of heifers, calving interval, productive lifetime of cows, incidence of clinical mastitis (CM) per cow per year, and SCS. Calving difficulty was divided into 4 score groups, which were (1) easy calving without help, (2) easy calving with help, (3) difficult calving without veterinarian assistance, and (4) difficult calving with veterinarian assistance, including a caesarean section. Stillbirth, defined as the proportion of dead calves per calving, included aborts, stillborn calves, and calves dead within $24 \mathrm{~h}$ after calving. Productive lifetime of cows was defined as the time period from the first calving to 
Table 2. Price of fresh matter (FM) and nutrient composition for feeding rations of different animal categories

\begin{tabular}{lcccc}
\hline $\begin{array}{l}\text { Category } \\
\text { of animals }\end{array}$ & $\begin{array}{c}\text { DM content } \\
(\mathrm{kg} \text { of DM } / \mathrm{kg} \text { of FM) }\end{array}$ & $\begin{array}{c}\text { Net energy content } \\
(\mathrm{MJ} / \mathrm{kg} \text { of DM) }\end{array}$ & $\begin{array}{c}\mathrm{PDI}^{1} \text { content } \\
(\mathrm{g} / \mathrm{kg} \text { of DM) }\end{array}$ & $\begin{array}{c}\text { Price } \\
(€ / \mathrm{kg} \text { of FM) }\end{array}$ \\
\hline Cows & 0.36 & 6.79 & 89 & 0.06 \\
Calves from birth to 3 mo & 0.67 & 9.75 & 202 & 1.11 \\
Calves from 3 to 6 mo & 0.38 & 6.85 & 101 & 0.07 \\
Breeding heifers & 0.30 & 5.78 & 70 & 0.04 \\
Animals in fattening & 0.35 & 6.77 & 82 & 0.05 \\
\hline
\end{tabular}

${ }^{1} \mathrm{PDI}=$ protein digestible in the intestine.

death or culling. The definition of SCS was based on a logarithmic transformation of SCC (average number of somatic cells/mL of milk).

Feed Efficiency Traits. Feed efficiency traits were RFI of cows, RFI of breeding heifers (from $180 \mathrm{~d}$ of age to calving), and RFI of animals in the fattening period (from $180 \mathrm{~d}$ of age to slaughter). Residual feed intake was defined as the difference between the actual daily DMI and the predicted daily DMI of an animal. The predicted daily DMI of each animal category was calculated according to the net energy and protein digestible in the intestine (PDI) requirements for growth, maintenance, milk production, and pregnancy and on the basis of the DM, net energy, and protein content in the feed ration of the corresponding animal category. Net energy and PDI requirements were calculated separately for each animal category, based on equations given by Vencl et al. (1991), Sommer et al. (1994), NRC (2000), and Petrikovič and Sommer (2002). The summary of the equations is given by Wolf et al. (2012). After net energy and PDI requirements were defined for each animal category, the predicted daily DMI was calculated on the basis of kilograms of feed DM (with given net energy and PDI content) needed to meet net energy and PDI requirements. The nutrient compositions for feeding rations used to define predicted DMI for each animal category are summarized in Table 2 . The feeding rations for different animal categories were balanced according to the Finnish feeding recommendations and on the most commonly used feeding strategies in Finland (MTT, 2010). Net energy and PDI contents of different feeds were calculated using the equations provided by Institut national de la recherche agronomique (INRA; Vermorel, 1989; Vérité and Peyraud, 1989). The actual daily DMI of an animal category was calculated as the sum of the predicted daily DMI and the average RFI of the corresponding animal category. Based on the definition of RFI (Williams et al., 2011), the average RFI of each above mentioned animal group was assumed to be zero; in other words, the mean of the actual DMI was expected to be equal to the mean of the predicted DMI in each animal group.

\section{Profit Function}

Total profit, calculated as the difference between discounted total revenues and costs per cow per year at the steady state of the cow herd structure, was taken as the criterion for the economic efficiency of the defined marketing strategies. In the model, the timing of the occurrence of revenues and costs was taken into account by discounting all revenues and costs occurring in the cow herd during a year, and in the life of progeny born in the herd that same year to the date of calving. The total profit was calculated as described by Wolfová et al. (2007a):

$$
\text { profit }=\operatorname{rev}^{\prime} \times \mathbf{N D E}^{(\mathrm{rev})}-\mathbf{c o s t}^{\prime} \times \mathbf{N D E}^{(\operatorname{cost})},[1]
$$

where profit is the total profit expressed in euro per cow per year; rev' and cost $^{\prime}$ are row vectors of revenues and costs, respectively, with the elements rev $_{i}$ and cost $t_{i}$, where $i$ is the animal category; and $\mathbf{N D E}^{(\mathrm{rev})}$ and $\mathbf{N D E}^{(\text {cost })}$ are column vectors of the numbers of discounted expressions for revenues and costs, respectively, with the elements $N D E_{i}^{(r e v)}$ and $N D E_{i}^{(c o s t)}$. An annual discount rate of $5 \%$ was used for revenues and costs. The main economic input parameters used for deriving the total profit were based on marketing circumstances in 2011 and are summarized in Tables 3 and 4. Costs and revenues unavailable for a given year were adjusted to the corresponding level by implementing the index of purchase and producer prices of the means of agricultural production (OSF, 2012a,b).

Revenues came from either sold surplus calves or from fattened bulls and heifers, sales of milk, slaughtered cows and heifers, sold breeding bulls, and the monetary value of slurry. Revenues coming from slaughtered animals were affected by liveweight at slaughter, dressing percentage, and the average price per kilogram of carcass weight, defined on the basis of the distribution of carcasses across fleshiness and fat-covering classes. The parameters describing the performance of progeny and the distribution of carcasses across fleshiness and fat-covering classes for slaughtered bulls and heifers are 
Table 3. Input parameters used for calculating revenues

\begin{tabular}{|c|c|}
\hline Parameter & Value \\
\hline Basic price for milk ${ }^{1}$ ( $€$ cent $/ \mathrm{kg}$ of milk) & 41.7 \\
\hline Bonus for milk protein percentage ( $€$ cent/unit of protein percent) & 6.3 \\
\hline Bonus for milk fat percentage ( $€$ cent/unit of fat percent) & 2.3 \\
\hline Deduction in milk price for milk in quality class $2^{2}$ ( $€$ cent $/ \mathrm{kg}$ of milk) & 2.5 \\
\hline Deduction in milk price for milk in quality class $3^{3}(€$ cent $/ \mathrm{kg}$ of milk) & 31.0 \\
\hline \multicolumn{2}{|l|}{ Price of sold animal $(€ /$ animal) } \\
\hline Breeding male calves sold to the AI breeding program & $3,700.0$ \\
\hline Female calves & 82.0 \\
\hline Male calves & 154.0 \\
\hline Monetary value of slurry $(€ / 100 \mathrm{~kg})$ & 0.5 \\
\hline
\end{tabular}

${ }^{1}$ Standard milk with fat content of $4.3 \%$, protein content of $3.3 \%$, and SCC $<250,000$ cells $/ \mathrm{mL}$.

${ }^{2}$ Milk with SCC between 250,000 and 400,000 cells/mL.

${ }^{3}$ Milk with SCC $>400,000$ cells $/ \mathrm{mL}$.

shown in Tables 5 and 6 . The distributions of carcasses across fleshiness and fat-covering classes were defined from slaughterhouse data received from the breeding organization Faba. The pricing system of Finnish meat producers' cooperative LSO Osuuskunta (Turku, Finland) for the year 2011 was applied to define the corresponding price for each fleshiness and fat-covering class.

Revenues coming from milk production were calculated according to the average annual milk production per cow and the average milk price. In Finland, the milk pricing system is based on both fat and protein content of milk, and the SCC level of milk. The average year 2011 price of 41.7 euro cents (including adjustment payments paid after calendar year for farmers) for a kilogram of standard milk with fat content of $4.3 \%$ and protein content of $3.3 \%$ was used as the basic milk price in the calculations. Bonuses of 6.3 and 2.3 euro cents for each additional percent of milk protein and fat above the reference values were paid, respectively. The same penalties per each reduced percent of milk protein and fat below the reference values were applied. The deduction of quality was taken into account by correcting the milk price according to the SCC level of milk. The basic milk price was paid for milk with SCC level $<250,000$ cells $/ \mathrm{mL}$. The milk price was reduced

Table 4. Input parameters used for calculating costs

\begin{tabular}{lc}
\hline Parameter & Value \\
\hline Fixed cost for ( $€$ per animal and day) & \\
Cows & 6.7 \\
Breeding heifers & 1.1 \\
Reared calves & 1.1 \\
Fattened bulls & 0.9 \\
Fattened heifers & 1.2 \\
Cost of veterinary treatment for & 110.0 \\
Cows $(€ /$ animal per reproductive cycle) & 5.0 \\
Calves $(€ /$ animal per rearing period) & 12.0 \\
Heifers $(€ /$ animal until calving) & 10.0 \\
Heifers in fattening $(€ /$ fattening period) & 7.0 \\
Bulls in fattening $(€ /$ fattening period) & 33.0 \\
Price of semen from AI dairy bulls $(€ /$ portion) & 31.0 \\
Price of semen from AI beef bulls $(€ /$ portion) & 94.0 \\
Cost of removing a dead adult animal $(€ /$ animal) & 51.0 \\
Cost of removing a dead calf $(€ /$ animal) & 268.0 \\
Veterinary cost connected with calving score $4(€ /$ calving) & \\
Time for labor related to calving difficulty $(\mathrm{h} /$ calving) & 0.2 \\
Calving score 2 & 1.5 \\
Calving score 3 & 3.7 \\
Calving score 4 & 17.5 \\
Cost of drugs for mastitis $(€ /$ case) & 15.5 \\
Cost of dose of drug for drying cows $(€ /$ udder quarter) & 160.0 \\
Charge of veterinary service for mastitis $(€ /$ case) & 2.0 \\
Time for labor related to mastitis $(\mathrm{h} /$ case) & 14.9 \\
Cost of herdsman's work hour $(€ / \mathrm{h})$ & 0.16 \\
Price of bedding material $(€ / \mathrm{kg})$ & 0.13 \\
Price of water $(€ / 100$ L) & \\
\hline &
\end{tabular}


Table 5. Input parameters for growth and carcass characteristics for Ayrshire $(\mathrm{AY})$ and Ayrshire $\times$ Limousin $(\mathrm{AY} \times \mathrm{LI})$ crosses

\begin{tabular}{lcc}
\hline Parameter & AY & AY $\times$ LI \\
\hline Birth weight (kg) & 40 & 42 \\
Male calves & 39 & 41 \\
Female calves & 624 & - \\
Mature weight of cows $(\mathrm{kg})$ & 1.0 & 1.1 \\
Daily gain in the rearing period (kg/d) & 0.8 & 0.9 \\
Male calves & & \\
Female calves & 1.0 & 1.1 \\
Daily gain in fattening (kg/d) & 0.8 & 0.9 \\
Bulls & 0.7 & - \\
Heifers & 634 & 668 \\
Daily gain of replacement heifers (kg/d) & 404 & 447 \\
Liveweight of fattened bulls at slaughter (kg) & \\
Liveweight of fattened heifers at slaughter (kg) & 404 \\
Dressing percentage (\%) & 50 & 52 \\
Heifers & 52 & 56 \\
Bulls & 48 & - \\
Cows &
\end{tabular}

by 2.5 euro cents per kilogram of milk with SCC level between 250,000 and 400,000 cells/mL and by 31 euro cents per kilogram of milk with SCC level $>400,000$ cells $/ \mathrm{mL}$. In the calculations, quota-free milk produc- tion was assumed, due to the abolition of the European Union milk quota system by 2015 .

It is unsure if the subsidy policies will stay in their current form in the future. Therefore, considerable uncertainty exists regarding the inclusion of subsidies in the calculations when deriving economic values of traits. Two scenarios considering agricultural subsidies were investigated: no agricultural subsidies included and agricultural subsidies included in the revenues. Finland is divided into 7 subsidy regions and the $\mathrm{C} 1$ (Eastern Finland) region was used as an example region when subsidies were applied in the calculations, adding the subsidies of $0.1 €$ per kilogram of milk and 412.5 $€$ per fattened animal to the revenues. The amounts of subsidies used in the investigation were based on values taken from ProAgria Agricultural Advisory Center's online farm management tool Tuottopehtori (ProAgria, 2013).

Costs included in the calculations were those for housing, feeding, health care, breeding, and fixed costs defined separately for each animal category. Housing costs resulted from bedding. The parameters used in the calculations of feeding costs for different animal

Table 6. Distribution of purebred Ayrshire (AY) and crossbred Ayrshire $\times$ Limousin $(\mathrm{AY} \times \mathrm{LI})$ carcasses across fleshiness and fat-covering classes

\begin{tabular}{|c|c|c|c|c|c|c|c|c|c|c|}
\hline \multirow[b]{3}{*}{ Fleshiness class $^{1}$} & \multicolumn{10}{|c|}{ Fat-covering class ${ }^{2}$} \\
\hline & \multicolumn{2}{|r|}{1} & \multicolumn{2}{|c|}{2} & \multicolumn{2}{|c|}{3} & \multicolumn{2}{|r|}{4} & \multicolumn{2}{|c|}{5} \\
\hline & $\mathrm{AY}$ & $\mathrm{AY} \times \mathrm{LI}$ & $\mathrm{AY}$ & $\mathrm{AY} \times \mathrm{LI}$ & $\mathrm{AY}$ & $\mathrm{AY} \times \mathrm{LI}$ & $\mathrm{AY}$ & $\mathrm{AY} \times \mathrm{LI}$ & $\mathrm{AY}$ & $\mathrm{AY} \times \mathrm{LI}$ \\
\hline \multicolumn{11}{|l|}{ Bull carcasses (\%) } \\
\hline $\mathrm{E}$ & 0.0 & 0.0 & 0.0 & 0.1 & 0.0 & 0.1 & 0.0 & 0.0 & 0.0 & 0.0 \\
\hline $\mathrm{U}$ & 0.0 & 0.0 & 0.0 & 1.3 & 0.0 & 1.7 & 0.0 & 0.1 & 0.0 & 0.0 \\
\hline $\mathrm{R}-$ & 0.0 & 0.8 & 1.1 & 12.5 & 1.7 & 14.9 & 0.3 & 3.0 & 0.0 & 0.2 \\
\hline $\mathrm{O}+$ & 0.1 & 0.5 & 5.3 & 8.6 & 6.8 & 8.2 & 0.9 & 1.5 & 0.0 & 0.1 \\
\hline $\mathrm{O}$ & 0.6 & 0.7 & 21.5 & 4.3 & 18.1 & 2.4 & 1.8 & 0.2 & 0.1 & 0.0 \\
\hline $\mathrm{O}_{-}$ & 1.3 & 0.3 & 20.8 & 0.9 & 9.4 & 0.3 & 0.7 & 0.1 & 0.0 & 0.0 \\
\hline $\mathrm{P}+$ & 1.0 & 0.3 & 5.5 & 0.1 & 1.0 & 0.0 & 0.1 & 0.0 & 0.0 & 0.0 \\
\hline $\mathrm{P}$ & 0.5 & 0.0 & 0.7 & 0.1 & 0.0 & 0.0 & 0.0 & 0.0 & 0.0 & 0.0 \\
\hline $\mathrm{P}-$ & 0.1 & 0.0 & 0.0 & 0.0 & 0.0 & 0.0 & 0.0 & 0.0 & 0.0 & 0.0 \\
\hline $\mathrm{R}-$ & 0.0 & 0.0 & 0.0 & 2.9 & 0.0 & 8.5 & 0.0 & 4.8 & 0.0 & 0.8 \\
\hline $\mathrm{O}+$ & 0.0 & 0.1 & 0.1 & 7.4 & 0.5 & 18.0 & 0.4 & 8.4 & 0.2 & 1.6 \\
\hline $\mathrm{O}$ & 0.0 & 0.2 & 1.6 & 9.3 & 5.8 & 13.7 & 3.9 & 5.6 & 1.2 & 1.0 \\
\hline $\mathrm{O}_{-}$ & 0.1 & 0.5 & 7.8 & 4.4 & 18.9 & 3.2 & 8.7 & 1.6 & 1.5 & 0.1 \\
\hline $\mathrm{P}+$ & 0.7 & 0.4 & 12.8 & 1.0 & 15.3 & 0.5 & 4.2 & 0.1 & 0.3 & 0.0 \\
\hline $\mathrm{P}$ & 2.5 & 0.2 & 7.2 & 0.1 & 3.8 & 0.0 & 0.7 & 0.0 & 0.1 & 0.0 \\
\hline $\mathrm{P}_{-}$ & 1.3 & 0.0 & 0.4 & 0.0 & 0.0 & 0.0 & 0.0 & 0.0 & 0.0 & 0.0 \\
\hline
\end{tabular}

${ }^{1}$ Fleshiness classes were based on the European SEUROP classification system: for fleshiness, 5 main classes (E, U, R, O, and P) were assigned, with $\mathrm{E}$ representing the best class and $\mathrm{P}$ representing the worst class. In addition, $\mathrm{R}, \mathrm{O}$, and $\mathrm{P}$ classes were divided into 3 subclasses (e.g., $\mathrm{R}+$, $\mathrm{R}$, and $\mathrm{R}-$ ), producing overall 11 different classes for fleshiness. When calculating an economic value for fleshiness, the classes were transformed into numbers, so that numbers from 1 to 11 were inserted for classes from $\mathrm{E}$ to $\mathrm{P}$-.

${ }^{2}$ Fat covering of a carcass was classified into 5 grades, numbered from 1 to 5 , with 1 used for low fat covering and 5 for high fat covering. 
categories are listed in Table 2. Feeding costs were calculated on the basis of feed needed to meet daily energy and protein requirements for growth, milk production, maintenance, and pregnancy and according to the average price per kilogram of fresh matter of the feeding ration with given DM, net energy, and protein content. Feeding components were assumed to be purchased for market prices. Feed prices in 2011 were taken from ProAgria Agricultural Advisory Center's online farm management tool Tuottopehtori (ProAgria, 2013). Health care costs included costs for veterinarian treatments, costs connected with CM incidence in the herd, dystocia costs, and costs for removing dead animals. Breeding costs were costs associated with AI, including the price of semen and costs for labor and services expressed per conception. Fixed costs included costs for labor, energy, reparations, and overhead costs and were expressed per animal per day.

\section{Derivation of Economic Values}

The marginal economic value for each trait was calculated as the numerical approximation of the partial derivative of the profit function with regard to the population mean of the trait considered as given by Wolfová et al. (2007a):

$$
e v_{l}=\left.\frac{\partial \text { profit }}{\partial T V_{l}}\right|_{T V_{l}=T V_{a v}},
$$

where $e v_{l}$ is the economic value of trait $l$ expressed in euro per unit of the trait per cow per year, profit is the profit per cow per year, $T V_{l}$ is the value of trait $l$, and $T V_{a v}$ is the population mean of trait $l$. When calculating economic values for traits with continuous variation, the genetic level of the trait considered was increased or decreased by $0.5 \%$ from the basic level (i.e., the trait means were multiplied by 1.005 and 0.995, respectively). This procedure could not be applied to RFI, because the trait means were assumed to be zero for all animal categories. Therefore, a value 0.05 $\mathrm{kg}$ of $\mathrm{DM} / \mathrm{d}$ was added to and subtracted from the trait mean of the appropriate animal category for which the economic value of RFI was calculated. When deriving economic values for categorical traits, with an assumed underlying normal distribution, the approach described by Wolfová et al. (1995) was used. The calculations were based on a threshold model where the underlying normal distribution of the trait was shifted to the left and right by multiplying the trait mean by 1.005 and 0.995 .

In general, 2 types of traits or trait components can be distinguished in terms of the number of discounted gene expressions (NDE): (1) direct traits realized once during the lifetime of an animal and (2) maternal traits realized repeatedly during the lifetime of a dam (Nitter et al., 1994). Several traits have both direct and maternal components. Although the marginal economic value of both direct and maternal components is usually the same, the NDE between the components can differ. Differences in the frequency and timing of expressions for trait components transferred by a particular parental selection group were taken into account by multiplying the marginal economic value of the trait by the NDE for direct and maternal trait components as follows:

$$
e w_{l j}=e v_{l} \times \mathrm{NDE}_{j},
$$

where $e w_{l j}$ is the economic weight for trait $l$ within component $j$ of that trait, $e v_{l}$ is the marginal economic value of trait $l$, and $\mathrm{NDE}_{j}$ is the $\mathrm{NDE}$ for component $j$ of trait $l$ for the selection group of 2-yr-old AI bulls. The gene flow method developed by Hill (1974) and Elsen and Mocquot (1974), using an investment period of $25 \mathrm{yr}$ and a discount rate of $5 \%$, was applied when calculating the NDE for direct and maternal components of traits. A detailed description of the calculation of the NDE is given by Nitter et al. (1994) and Wolfová et al. (2007b).

\section{Relative Economic Weight of Traits}

A direct comparison of the economic importance between different traits is difficult because marginal economic values are expressed in different units. To compare the economic importance of different traits, first, standardized economic weights $\left(\operatorname{ews}_{l j}\right)$ were defined as follows:

$$
e w s_{l j}=e w_{l j} \times s_{l j}
$$

where $e w_{l j}$ is the economic weight for trait $l$ within component $j$ of that trait and $s_{l j}$ is the genetic standard deviation for component $j$ of trait $l$. Then, the relative economic weights of traits were calculated as follows:

$$
e w r_{l j}=100 \times \frac{\left|e w s_{l j}\right|}{\sum_{l} \sum_{j}\left|e w s_{l j}\right|},
$$

where $e w r_{l j}$ is the relative economic weight for component $j$ of trait $l$ and $\left|e w s_{l j}\right|$ is the absolute value of the standardized economic weight for component $j$ of trait $l$.

Genetic standard deviations used for standardizing the economic values were based on estimates used in 
Table 8. Modeled herd structure in the steady state of the Markov chain

\begin{tabular}{|c|c|c|c|c|}
\hline \multirow[b]{3}{*}{ Item } & \multicolumn{4}{|c|}{ Marketing strategy $^{1}$ (no. of animals ${ }^{2}$ ) } \\
\hline & \multirow[b]{2}{*}{ A } & \multirow[b]{2}{*}{ B } & \multicolumn{2}{|c|}{$\mathrm{B}^{3}$} \\
\hline & & & Dairy & $\begin{array}{c}\text { Crossbred } \\
\text { progeny }\end{array}$ \\
\hline \multicolumn{5}{|l|}{ Cows in parity ${ }^{4}$} \\
\hline 1 & 34.70 & & & \\
\hline 2 & 26.46 & & & \\
\hline 3 & 18.02 & & & \\
\hline 4 & 10.67 & & & \\
\hline 5 & 5.54 & & & \\
\hline 6 & 2.59 & & & \\
\hline 7 & 1.14 & & & \\
\hline 8 & 0.55 & & & \\
\hline 9 & 0.22 & & & \\
\hline$\geq 10$ & 0.01 & & & \\
\hline \multicolumn{5}{|l|}{ Progeny } \\
\hline Calves born alive & 95.71 & 95.71 & 86.00 & 9.66 \\
\hline Calves reared & 92.81 & 92.81 & 83.40 & 9.36 \\
\hline Bulls fattened to target slaughter weight & - & 46.06 & 41.30 & 4.64 \\
\hline Heifers fattened to target slaughter weight & - & 9.57 & 4.86 & 4.68 \\
\hline Male calves sold for export & 47.51 & - & - & - \\
\hline Female calves sold for export & 9.62 & - & - & - \\
\hline Heifers reared for replacement & 36.95 & 36.95 & 36.95 & - \\
\hline
\end{tabular}

${ }^{1}$ Marketing strategy A: surplus calves are sold at a young age; marketing strategy B: surplus calves are fattened on dairy farms.

${ }^{2}$ Numbers are expressed per 100 cows per year.

${ }^{3}$ System with $10 \%$ crossing of dairy cows with beef bulls.

${ }^{4}$ Valid for both marketing strategies (reproductive cycle; i.e., calving interval is $413 \mathrm{~d}$ ).

dies included in the revenues, are shown in Table 10. These marginal economic values express the change in profit per cow per year when the mean value of the trait is increased by 1 unit. The marginal economic values for the scenario where $10 \%$ of the dairy cows were mated with beef bulls did not differ substantially from the marginal economic values for the purebred dairy production system. Therefore, the marginal economic values are given only for the purebred dairy production system. When surplus calves were exported (marketing strategy A), negative economic values were obtained for SCS, CM incidence, calving difficulty score, stillbirth, birth weight, calf mortality in the rearing period, fleshiness, fat covering, mature weight, calving interval, interval between first AI and conception of heifers, and RFI of heifers and cows. This implies that an increase in the mean value of these traits would result in a decrease in total profit. In contrast to marketing strategy A, positive marginal economic values for calving difficulty score, stillbirth, birth weight, and calf mortality

Table 9. Economic characteristics for the modeled marketing strategies

\begin{tabular}{|c|c|c|c|c|c|}
\hline \multirow[b]{3}{*}{ Item } & \multicolumn{5}{|c|}{ Marketing strategy $^{1}$} \\
\hline & \multicolumn{3}{|c|}{ Without subsidies } & \multicolumn{2}{|c|}{ With subsidies $^{2}$} \\
\hline & $\mathrm{A}$ & $\mathrm{B}$ & $\mathrm{B}^{3}$ & $\mathrm{~A}$ & B \\
\hline Total revenues $(€ /$ cow per year $)$ & $3,392.1$ & $3,680.0$ & $3,686.3$ & $3,392.1$ & $3,680.0$ \\
\hline Total costs $(€ /$ cow per year $)$ & $4,008.5$ & $4,642.1$ & $4,634.3$ & $4,008.5$ & $4,642.1$ \\
\hline Governmental subsidies $(€ /$ cow per year $)$ & - & - & - & 779.7 & 982.5 \\
\hline Profit $(€ /$ cow per year $)$ & -616.4 & -962.1 & -948.0 & 163.4 & 20.4 \\
\hline Profitability $^{4}(\%)$ & -15.4 & -20.7 & -20.5 & 4.1 & 0.4 \\
\hline
\end{tabular}


Table 10. Marginal economic values of traits (in $€ /$ unit of the trait per cow per year)

\begin{tabular}{|c|c|c|c|c|}
\hline \multirow[b]{3}{*}{ Trait (€/unit) } & \multicolumn{4}{|c|}{ Marketing strategy $^{1}$} \\
\hline & \multicolumn{2}{|c|}{ Without subsidies } & \multicolumn{2}{|c|}{ With subsidies } \\
\hline & A & $\mathrm{B}$ & A & $\mathrm{B}$ \\
\hline 305-d milk yield ${ }^{2}(€ / \mathrm{kg})$ & 0.3 & 0.3 & 0.4 & 0.4 \\
\hline Protein percentage $(€ / \%)$ & 404.5 & 404.5 & 404.5 & 404.5 \\
\hline Fat percentage $(€ / \%)$ & 109.0 & 109.0 & 109.0 & 109.0 \\
\hline $\operatorname{SCS}^{3}(€ /$ score $)$ & -84.3 & -84.3 & -84.3 & -84.2 \\
\hline Clinical mastitis incidence $(€ /$ cases per cow per year) & -389.4 & -389.4 & -389.4 & -389.4 \\
\hline Calving difficulty score $(€ /$ score $)$ & -22.1 & 4.6 & -25.8 & -14.6 \\
\hline Stillbirth $(€ / \%)$ & -0.3 & 5.6 & -0.3 & 2.1 \\
\hline Calf mortality in rearing $(€ / \%)$ & -1.3 & 3.1 & -1.3 & -0.4 \\
\hline Productive lifetime of cows $(€ / \mathrm{yr})$ & 88.2 & 17.2 & 121.9 & 91.9 \\
\hline Birth weight $(€ / \mathrm{kg})$ & -0.2 & 0.5 & -0.2 & 0.5 \\
\hline Mature weight $(€ / \mathrm{kg})$ & -1.0 & -1.7 & -1.0 & -1.7 \\
\hline Dressing percentage $(€ / \%)$ & 2.8 & 10.0 & 2.8 & 10.0 \\
\hline Daily gain of calves in the rearing period ( $€ / g$ per day) & 0.3 & 0.3 & 0.3 & 0.3 \\
\hline Daily gain in fattening $(€ / g$ per day) & - & 0.4 & - & 0.4 \\
\hline Fat covering $(€ /$ score $)$ & -7.6 & -13.1 & -7.6 & -13.0 \\
\hline Fleshiness $(€ /$ score $)$ & -0.2 & -8.2 & -0.2 & -8.0 \\
\hline Calving interval $(€ / \mathrm{d})$ & -4.8 & -1.6 & -4.9 & -3.5 \\
\hline Interval between first $\mathrm{AI}$ and conception of heifers $(€ / d)$ & -1.6 & -1.4 & -1.6 & -1.5 \\
\hline $\mathrm{RFI}^{4}$ of animals in fattening ( $€ / \mathrm{kg}$ of DM per day) & $\mathcal{L}^{1.0}$ & -29.5 & - & -29.5 \\
\hline RFI of breeding heifers ( $€ / \mathrm{kg}$ of DM per day) & -25.5 & -25.5 & -25.5 & -25.5 \\
\hline RFI of cows $(€ / \mathrm{kg}$ of DM per day) & -55.8 & -55.8 & -55.8 & -55.8 \\
\hline
\end{tabular}

${ }^{1}$ Marketing strategy A: surplus calves are sold at a young age; marketing strategy B: surplus calves are fattened on dairy farms.

${ }^{2}$ Milk with average fat content of $4.3 \%$ and protein content of $3.4 \%$.

${ }^{3}$ Somatic cell score is defined as $\log _{2}(\mathrm{SCC} / 100,000)+3$.

${ }^{4} \mathrm{RFI}=$ residual feed intake.

in the rearing period were found in marketing strategy $\mathrm{B}$, when no subsidies were included in the calculations. Positive marginal economic values were obtained for traits, which, when increased, caused a decrease in the number of calves available for fattening. This means that fattening of surplus calves on dairy farms is unprofitable and each increase in the number of fattened animals would increase the economic loss. However, in marketing strategy B with subsidies, the better profitability of applying fattening due to subsidies paid per fattened animal resulted in negative marginal economic values for calving difficulty score and calf mortality in the rearing period. Also differences in the marginal economic values for stillbirth, productive lifetime of cows, and calving interval obtained between the scenarios, accounting for and not accounting for subsidies, can be mainly explained by the fact that the economic values of these traits are affected by the profitability of fattening animals on dairy farms.

The relative economic weights of traits and of the direct and maternal trait components for both marketing strategies are summarized in Table 11. When comparing the relative economic weights of all traits in the scenarios, where subsidies were not included in the revenues, the highest relative importance was found for $305-\mathrm{d}$ milk yield, which contributed 34 and $29 \%$ to the sum of the absolute values of the standardized economic weights over all traits in marketing strategy A and $\mathrm{B}$, respectively. In marketing strategy $\mathrm{A}$, the second most important trait was protein percentage (13\%), followed by calving interval (9\%) and fat percentage (8\%). Clinical mastitis incidence, production lifetime, ADG of calves in the rearing period, mature weight, and RFI of cows reached relative weights between 3 and $7 \%$, whereas the relative economic importance for all other traits was under $3 \%$. The relative economic importance was close to zero for direct and maternal birth weight and fleshiness $(\leq 0.1 \%)$. In marketing strategy $\mathrm{B}$, the second most important trait after 305-d milk yield was protein percentage $(11 \%)$, followed closely by mature weight of cows (11\%) and fat percentage (7\%). Average daily gain in fattening, direct stillbirth, direct calf mortality in rearing, ADG in the rearing period, and RFI of cows reached relative weights between 3 and $5 \%$. The relative economic importance for all other traits was under $3 \%$. The lowest economic importance was found for direct and maternal calving difficulty score and direct and maternal birth weight $(\leq 0.2 \%)$. When comparing scenarios, accounting for and not accounting for subsidies, the relative weight of 305-d milk yield was 
substantially higher with subsidies in both marketing strategies. In marketing strategy B, substantial differences were also found between relative weights for productive lifetime of cows, calving interval, maternal and direct stillbirth, and maternal and direct calf mortality in rearing.

When the studied traits were assigned to sets of traits, and not taking subsidies into account, the sums of relative weights for production, functional, carcass and growth, and feed efficiency traits were 55, 26, 12, and $6 \%$, respectively, in marketing strategy $\mathrm{A}$ and 47 , 22,24 , and $7 \%$ in marketing strategy B. When subsidies were taken into account, the corresponding proportions were $58,25,11$, and $6 \%$ in marketing strategy $\mathrm{A}$ and $54,16,23$, and $7 \%$ in marketing strategy B.

\section{DISCUSSION}

Our results clearly indicate that the profitability of current Finnish milk production and especially combined milk and beef production is strongly dependent on agricultural subsidies. However, it is debatable if the agricultural subsidies should be included in the calculations of economic values due to uncertainties in the stability and continuity of the current subsidy program. In addition, the amount of subsidies paid to farmers differs greatly, depending on the farm location, leading to differences in the economic values of traits derived for a specific subsidy region. When subsidies were not included in the calculations, the economic profitability of both marketing strategies under production conditions in 2011 was negative, due to low milk and beef prices and high production costs. When subsidies were included in the calculations, they accounted for 19 and $21 \%$ of the total revenues in marketing strategies A and $\mathrm{B}$, respectively. Finland is divided into 7 subsidy regions and according to ProAgria Agricultural Advisory Center's online farm management tool Tuottopehtori (ProAgria, 2013), in 2012, subsidies covered from 12 to $34 \%$ of the total income from milk production, depending on the location of the farm.

In our study, subsidies were paid per kilogram of produced milk and per fattened animal, affecting the economic values of traits that are associated with the revenues from milk and slaughtered animals. However, in the future, economic values of other traits may also be influenced by subsidies or taxes (for example, if the environmental tax related to the feed price is intro-

Table 11. Relative economic weights of traits (in percentage of the sum of standardized economic weights over all traits)

\begin{tabular}{|c|c|c|c|c|}
\hline \multirow[b]{3}{*}{ Trait } & \multicolumn{4}{|c|}{ Marketing strategy $^{1}$} \\
\hline & \multicolumn{2}{|c|}{ Without subsidies } & \multicolumn{2}{|c|}{ With subsidies } \\
\hline & A & $\mathrm{B}$ & $\mathrm{A}$ & $\mathrm{B}$ \\
\hline 305-d milk yield & 34.0 & 29.3 & 39.6 & 35.6 \\
\hline Protein percentage & 13.1 & 11.3 & 11.5 & 10.4 \\
\hline Calving interval & 9.3 & 2.6 & 8.5 & 5.5 \\
\hline Fat percentage & 8.0 & 6.8 & 7.0 & 6.4 \\
\hline Mature weight & 7.0 & 10.6 & 6.2 & 9.7 \\
\hline Productive lifetime of cows & 4.6 & 0.8 & 5.6 & 3.8 \\
\hline Residual feed intake of cows & 4.6 & 3.9 & 4.1 & 3.6 \\
\hline Daily gain of calves in rearing period & 4.0 & 4.5 & 3.5 & 4.2 \\
\hline Clinical mastitis incidence & 3.4 & 2.9 & 3.0 & 2.7 \\
\hline Interval between first AI and conception of heifers & 2.8 & 2.0 & 2.5 & 2.1 \\
\hline Calf mortality in rearing, direct & 1.8 & 3.6 & 1.6 & 0.4 \\
\hline Residual feed intake of breeding heifers & 1.8 & 1.5 & 1.6 & 1.4 \\
\hline SCS & 1.5 & 1.3 & 1.4 & 1.2 \\
\hline Calving difficulty score, direct & 1.0 & 0.2 & 1.0 & 0.5 \\
\hline Calf mortality in rearing, maternal & 0.8 & 1.7 & 0.8 & 0.2 \\
\hline Dressing percentage & 0.8 & 2.5 & 0.7 & 2.3 \\
\hline Calving difficulty score, maternal & 0.6 & 0.1 & 0.6 & 0.3 \\
\hline Fat covering & 0.4 & 0.7 & 0.4 & 0.6 \\
\hline Stillbirth, direct & 0.3 & 3.8 & 0.2 & 1.3 \\
\hline Stillbirth, maternal & 0.2 & 2.6 & 0.2 & 0.9 \\
\hline Birth weight, direct & 0.1 & 0.2 & 0.1 & 0.2 \\
\hline Birth weight, maternal & 0.1 & 0.1 & 0.1 & 0.1 \\
\hline Fleshiness & 0.0 & 0.6 & 0.0 & 0.6 \\
\hline Daily gain in fattening & - & 4.6 & - & 4.3 \\
\hline Residual feed intake of animals in fattening & - & 1.8 & - & 1.6 \\
\hline
\end{tabular}


duced). Considering the breeding goal traits investigated in our study, an increased feed price would shift the economic emphasis from production traits particularly toward feed efficiency traits and mature weight of cows. Hence, even though the economic importance of feed efficiency traits under production conditions in 2011 was minor, their relative importance will likely increase due to increasing requirements to mitigate the environmental impact of livestock production in the future. For instance, when the feed price was increased by $20 \%$ in marketing strategy A and sets of traits considered, the sum of the relative economic weights for feed efficiency traits increased by 1.0 percentage point, and in contrast, the sum of the relative economic weights for production traits decreased by 3.6 percentage points. When considering economic weights for individual traits, a major change was found in the economic weight for mature weight of cows, which changed by 1.2 percentage points, favoring smaller BW.

The marginal economic values of traits related to the survival of calves and beef production traits differ greatly between the 2 evaluated marketing strategies, whereas quite similar economic values for milk production and feed efficiency traits were found. In beef cattle production, Krupa et al. (2005) also observed substantial variability in the marginal economic values between marketing strategies (surplus calves were fattened or exported after weaning), caused by the differences between the revenues and costs of different animal categories. On the basis of our results, it might be beneficial to construct 2 separate customized indexes for within-farm selection for farms applying either fattening or export of surplus calves. This would allow choosing economically the most appropriate dairy sires for specific goals. However, at a national level, as most of Finnish beef comes from dairy cattle, the traits improving the profitability of milk production as well as beef production should be taken into consideration when constructing a selection index for dairy bulls in an AI breeding program. Our results showed that mating $10 \%$ of dairy cows with Limousin bulls did not substantially affect the economic values of traits. Therefore, taking crossing into account in the dairy cattle breeding program is not needed, at least when the crossing percentage is low.

When subsidies were not included in the revenues and the surplus calves were fattened on dairy farms, an unprofitable production of fattened animals led to positive economic values for traits (e.g., stillbirth and calving difficulty score), which, when increased, caused a decrease in the number of calves available for fattening. A positive economic value for stillbirth was also observed by Nielsen et al. (2004) under the production circumstances where subsidy on beef was removed and markets were liberated in the European Union. This led to an unprofitable production of fattened bulls on dairy farms. According to Wolfová et al. (2006), under production conditions causing a negative profit, economic values can change in magnitude or even in sign. They observed that the profitability of each section of the production system (e.g., fattening and calf rearing for sale), instead of the total profit of the production system, should be positive to avoid an underestimation of the economic importance of functional traits. Similarly, Krupa et al. (2005) found that the economic values of traits, which affect the number of animals in the category of progeny producing an economic loss, are biased in terms of the true economic importance of traits considered. Hence, as Wolfová et al. (2005b) suggested, further research is needed to examine how to treat such uncertainty considering the validity of derived economic importance of traits under unprofitable production.

Differences in the definition of traits, methods used for deriving economic values, and management systems make a direct comparison of economic values derived from different studies difficult. Nevertheless, some general comparisons can still be made. Considering milk production traits, the economic values are strongly influenced by the used milk payment system (Gibson et al., 1992). The reported economic values for milk yield, defined as milk volume, have mainly been negative due to the payment system where the price for milk volume is low or negative (Vargas et al., 2002; Veerkamp et al., 2002). Under the 2007 production conditions, Pedersen et al. (2008) also found a negative economic value of milk yield $(-0.029 € / \mathrm{kg})$ for Nordic Red dairy cattle, whereas a slightly positive economic value was reported for Finnish Ayrshire cattle in southern Finland (0.015 $€ / \mathrm{kg})$. In our study, milk yield was defined as 305-d milk yield with an average fat and protein content. This led to positive economic values for 305-d milk yield $(0.28$ to $0.37 € / \mathrm{kg})$. Those economic values were close to the reported economic value for standard milk $(0.23$ $€ / \mathrm{kg}$ ) for Finnish Ayrshire cattle in southern Finland (Pedersen et al., 2008). The economic values for fat percentage and protein percentage are strongly dependent on the ratio of the price for protein and fat and on the price for feed. In the calculations for Nordic Red dairy cattle by Pedersen et al. (2008), the ratio for the economic values of kilograms of protein and fat (1:3.6) was similar to the ratio calculated for the economic values of protein and fat percentage (1:3.7) in our study.

Considering beef production traits, the relative economic weights for fat covering and fleshiness were low, which can be explained by small differences in the prices between different fleshiness and fat-covering classes. Carcass traits are not included in the current NTM 
index for Nordic Red dairy cattle, which is supported by the low economic importance of carcass traits found in our study. However, the relative economic weights between 4 and $5 \%$ for growth traits (ADG of calves in the rearing period and ADG of animals in fattening) indicates that selection for growth traits in dairy cattle results in economic benefits for both beef and dairy production, by producing faster growing bulls and replacement heifers. In Finland, where the majority of beef comes from dairy cattle, the importance of beef production traits in the breeding goal should be discussed. Moreover, from an environmental point of view, beef production from dairy cows has been shown to produce fewer emissions per kilogram of produced meat than beef production from suckler cows (Casey and Holden, 2006). This also highlights the importance of increasing the efficiency of beef production from dairy cows.

Considering the mature weight of cows, a relatively high economic importance, accounting for 6 to $11 \%$ of the sum of the absolute values of the standardized economic weights over all traits, was found. In earlier studies, the reported economic values for mature weight have mostly been dependent on beef and feed prices. The economic values for mature weight have mainly been negative, ranging between -1.28 and $0.02 € / \mathrm{kg}$ per cow per year, as shown in the review of Koenen et al. (2000). The economic value obtained for mature weight in marketing strategy $\mathrm{A}(-1.0 € / \mathrm{kg}$ per cow per year) was in agreement with findings from earlier studies, whereas the economic value for mature weight $(-1.7 € / \mathrm{kg}$ per cow per year) in marketing strategy $\mathrm{B}$ was below that given range. Mature weight of cows reached a negative economic value, caused by the fact that the marginal revenues from the higher slaughter weight of cows did not cover the marginal costs associated with energy requirements for the maintenance of heavier animals.

Substantial weight has been placed on functional traits in the NTM index for Nordic Red dairy cattle (Pedersen et al., 2008). Considering functional traits investigated in our study, calving interval was shown to be the third most important trait when not applying fattening on dairy farms. However, relatively low economic weights were found for other functional traits. Great differences also were found in economic values of functional traits between marketing strategies and scenarios considering the inclusion of subsidies. The economic value of productive lifetime of cows in Finnish Ayrshire cattle varied from 0.03 to $0.33 € / d$ between the studied scenarios. A change in productive lifetime of cows affected average milk production per cow per year, the number of heifers needed for replacement, the number of surplus calves, revenues from culled cows, and costs for involuntarily culled cows. This caused strong sensitivity in the economic value of productive lifetime of cows in the studied scenarios. A somewhat higher economic value for longevity $(0.41 € / d)$ was found by Pedersen et al. (2008) for Finnish Ayrshire cattle in southern Finland. In general, great differences exist between the economic values of productive lifetime of cows reported in different studies. For example, Wolfová et al. (2007a) found an economic value of 0.20 $€ / d$ for Holstein-Friesian cattle in the Czech Republic, whereas Toivakka et al. (2005) reported economic values of 0.67 and $1.12 € / d$ for Finnish Ayrshire and Holstein-Friesian cattle, respectively.

In general, when comparing the economic importance of traits resulting from the current study with the economic importance reported for breeding goal traits for Nordic Red dairy cattle, milk production traits received substantially more emphasis in our study than in the NTM index (Pedersen et al., 2008). This is partly due to the fact that more weight has been placed on health and functional traits in the NTM index, additionally emphasizing the non-economic value of the traits. The increased interest of the dairy industry to pay attention to the socio-ethical aspects of animal production, such as animal welfare and environmental impact of animal production, will probably lead to the inclusion of new traits in the breeding goal. In addition, it will likely shift the emphasis even more from milk production traits to functional and health traits.

Increasing requirements to mitigate the environmental impact of livestock production is likely to increase the economic importance of improving feed efficiency in dairy cattle. In addition, the possible use of genomic selection for RFI in the future would increase the economic benefits of selecting for RFI due to the increased accuracy of selection and reduced costs of measuring RFI. To our knowledge, this is the first study to explore an economic value of RFI in the breeding goal for dairy cattle. However, it would be important to study the effect of including feed efficiency traits in the breeding goal by estimating the expected genetic response in feed efficiency traits and, in addition, examining how this inclusion would affect the expected genetic response in the current breeding goal traits in the Nordic dairy cattle selection program. Also a cost-benefit analysis of including a costly test period for feed efficiency should be carried out or, alternatively, a low-cost approximate on-farm test should be studied.

\section{CONCLUSIONS}

As the results of this study have shown, the profitability of Finnish milk production relies strongly on subsidies. The economic values for functional traits 
that were derived under these unprofitable production conditions might be biased in terms of the true economic importance of traits. However, due to uncertainties in the stability and continuity of the current subsidy program, the inclusion of subsidies in the revenues does not appear to be an appropriate method to determine the optimum economic weights of traits in the breeding goal. The substantial differences were found in the relative weights of traits between the different marketing strategies for surplus calves. This indicates that it could be beneficial to construct separate selection indexes used in different production systems at the dairy farm level, especially considering relative weights of beef production traits in different indexes. Under production conditions in 2011, the relative economic weights for the studied feed efficiency traits were relatively low. However, the importance of improving feed efficiency in dairy production might increase in the near future due to continuously increasing requirements to mitigate the environmental impact of livestock production. It would be important to study the expected genetic response in feed efficiency traits and the current breeding objective traits in the Nordic dairy cattle breeding program, also taking into account the costs for alternative measures of feed efficiency. This should help to evaluate the profitability of selection for feed efficiency in terms of more economically and environmentally efficient milk and beef production.

\section{ACKNOWLEDGMENTS}

The present study is a part of MAILI projects, financed by The Centre for Economic Development, Transport and the Environment for North Savonia (Kuopio, Finland), and AnGR-NordicNET, financed by Nordic Council of Ministers and NordForsk (Oslo, Norway). The authors thank S. Karjalainen (University of Helsinki, Helsinki, Finland) for collecting and calculating parameters needed for the derivation of economic values and S. Jaakkola and M. Tuori (both from University of Helsinki) for their help in defining feeding strategies and nutrient contents of feeds. The data were received from Faba (Hollola, Finland) and LSO Osuuskunta (Turku, Finland). The development of the ECOWEIGHT software was supported by the project MZE 0002701404 of the Ministry for Agriculture of the Czech Republic (Prague).

\section{REFERENCES}

Bauman, D. E., S. N. McCutcheon, W. D. Steinhour, P. J. Eppard, and S. J. Sechen. 1985. Sources of variation and prospects for improvement of productive efficiency in the dairy cow: A review. J. Anim. Sci. 60:583-592.
Casey, J. W., and N. M. Holden. 2006. Quantification of GHG emissions from suckler-beef production in Ireland. Agric. Syst. 90:7998.

Elsen, J. M., and J. C. Mocquot. 1974. Méthode de prévision de l'evolution du niveau génétique d'une population soumise à une opération de sélection et dont les génerations se chevauchent. INRA Bull. Tech. Dépt. Génét. Anim. 17:30-54.

Gibson, J. P., N. Graham, and E. B. Burnside. 1992. Selection indexes for production traits of Canadian dairy sires. Can. J. Anim. Sci. $72: 477-491$.

Hill, W. G. 1974. Prediction and evaluation of response to selection with overlapping generations. Anim. Prod. 18:117-139.

Interbull. 2011a. Genetic evaluations. Production. Accessed Mar. 1, 2012. http://www-interbull.slu.se/eval/framesida-prod.htm.

Interbull. 2011b. Genetic evaluations. Female fertility. Accessed Mar. 1, 2012. http://www-interbull.slu.se/Female_fert/framesida-fert. htm.

Interbull. 2011c. Genetic evaluations. Udder health. Accessed Mar. 1, 2012. http://www-interbull.slu.se/udder/framesida-udder.htm.

Jamrozik, J., J. Fatehi, G. J. Kistemaker, and L. R. Schaeffer. 2005. Estimates of genetic parameters for Canadian Holstein female reproduction traits. J. Dairy Sci. 88:2199-2208.

Koch, R. M., L. A. Swiger, D. Chambers, and K. E. Gregory. 1963. Efficiency of feed use in beef cattle. J. Anim. Sci. 22:486-494.

Koenen, E. P. C., P. B. M. Berentsen, and A. F. Groen. 2000. Economic values of live weight and feed-intake capacity of dairy cattle under Dutch production circumstances. Livest. Prod. Sci. 66:235-250.

Korver, S., E. A. M. van Eekelen, H. Vos, G. J. Nieuwhof, and J. A. M. van Arendonk. 1991. Genetic parameters for feed intake and feed efficiency in growing dairy heifers. Livest. Prod. Sci. 29:49-59.

Krupa, E., M. Wolfová, D. Peškovičová, J. Huba, and Z. Krupová 2005. Economic values of traits for Slovakian Pied cattle under different marketing strategies. Czech J. Anim. Sci. 10:483-492.

Liinamo, A.-E., M. Ojala, and J. van Arendonk. 1999. Relationships of body weight and carcass quality traits with first lactation milk production in Finnish Ayrshire cows. Livest. Prod. Sci. 60:271279 .

Matilda Agricultural Statistics. 2013. Number of livestock. Information Centre of the Ministry of Agriculture and Forestry, Tike. Accessed Oct. 28, 2013. http://www.maataloustilastot.fi/en/numberof-livestock.

Miglior, F., B. L. Muir, and B. J. Van Doormaal. 2005. Selection indices in Holstein cattle of various countries. J. Dairy Sci. 88:12551263.

MTT. 2010. Rehutaulukot ja ruokintasuositukset (Feed tables and feeding recommendations), Agrifood Research Finland. Accessed Jan. 12, 2012. https://portal.mtt.fi/portal/page/portal/ Rehutaulukot/feed_tables_english.

MTTL. 2012. Suomen maatalous ja maaseutuelinkeinot 2012. Agrifood Research Finland, Economic Research (MTTL), Publications 112. MTTL, Vammala, Finland.

NRC. 2000. Nutrient Requirements of Beef Cattle. 7th rev. ed. Natl. Acad. Press, Washington, DC.

Nielsen, H. M., A. Groen, J. Pedersen, and P. Berg. 2004. Stochastic simulation of economic values and their standard deviations for production and functional traits in dairy cattle under current and future Danish production circumstances. Acta Agric. Scand. A Anim. Sci. 54:113-126.

Nitter, G., H. U. Graser, and S. A. Barwick. 1994. Evaluation of advanced industry breeding schemes for Australian beef cattle. 1. Method of evaluation and analysis for an example population structure. Aust. J. Agric. Res. 45:1641-1656.

OSF (Official Statistics of Finland). 2012a. Index of purchase prices of the means of agricultural production. Helsinki: Statistics Finland. Accessed May 21, 2012. http://tilastokeskus.fi/til/ttohi/ index_en.html.

OSF (Official Statistics of Finland). 2012b. Index of producer prices of agricultural products. Helsinki: Statistics Finland. Accessed May 21, 2012. http://tilastokeskus.fi/til/mthi/index_en.html. 
Parkkonen, P., A.-E. Liinamo, and M. Ojala. 2000. Estimates of genetic parameters for carcass traits in Finnish Ayrshire and HolsteinFriesian . Livest. Prod. Sci. 64:203-213.

Pedersen, J., M. K. Sørensen, M. Toivonen, J.-A. Eriksson, and G. P. Aamand. 2008. Report on economic basis for a Nordic total merit index. Accessed May 23, 2012. http://www.nordicebv.info/NR/ rdonlyres/B618C0E5-FF6F-4D31-8F86-B3CE4A140043/0/NAV_ TMI_report_lastversion_131108.pdf.

Petrikovič, P., and A. Sommer. 2002. Potreba živín pre hovädzí dobytok. VÚŽV, Nitra, Slovak Republic.

ProAgria. 2012. ProAgrian tuotosseurantatulokset osoittavat: Tehokkuutta maidontuotantoon saatavissa nuorkarjaan ja laadukkaaseen säilörehuun panostamalla. Newsletter 25.4.2012. Accessed June 25, 2012. https://portal.mtt.fi/portal/page/portal/ProAgria/ajankohtaista/BE7B4C02F47E536BE0430392D0C1BCF6.

ProAgria. 2013. ProAgria Agricultural Advisory Center's on-line farm management tool Tuottopehtori. Accessed Jan. 23, 2012. http:// www.proagria.fi/tuottopehtori/.

Pryce, J. E., J. Arias, P. J. Bowman, S. R. Davis, K. A. Macdonald, G. C. Waghorn, W. J. Wales, Y. J. Williams, R. J. Spelman, and B. J. Hayes. 2012. Accuracy of genomic predictions of residual feed intake and 250-day body weight in growing heifers using 625,000 single nucleotide polymorphism markers. J. Dairy Sci. 95:2108-2119.

Sommer, A., Z. Čerešňáková, Z. Frydrych, O. Králík, Z. Králíková, A. Krása, M. Pajtáš, P. Petrikovič, J. Pozdíšek, M. Šimek, J. Třináctỳ, B. Vencl, and L. Zeman. 1994. Potřeba živin a tabulky výživné hodnoty krmiv pro přežvýkavce. CAZV, Pohořelice, Czech Republic

Thoma, G., J. Popp, D. Nutter, D. Shonnard, R. Ulrich, M. Matlock, D. S. Kim, Z. Neiderman, N. Kemper, C. East, and F. Adom 2013. Greenhouse gas emissions from milk production and consumption in the United States of America: A cradle-to-grave life cycle assessment circa 2008. Int. Dairy J. 31:S3-S14. http:// dx.doi.org/10.1016/j.idairyj.2012.09.010.

Toivakka, M., J. I. Nousiainen, and E. A. Mäntysaari. 2005. Estimation of economic values of longevity and other functional traits in Finnish dairy cattle. Paper CG2.25 in 65th Annual Meeting of the EAAP, Uppsala, Sweden. Accessed June 20, 2012. http:// www.eaap.org/Previous_Annual_Meetings/2005Uppsala/Papers/ CG2.25_Toivakka.pdf.

Van Arendonk, J. A. M., G. L. Nieuwhof, H. Vos, and S. Korver. 1991 Genetic aspects of feed intake and efficiency in lactating dairy heifers. Livest. Prod. Sci. 9:263-275.

Vargas, B., A. F. Groen, M. Herrero, and J. A. M. Van Arendonk. 2002. Economic values for production and functional traits in Holstein cattle in Costa Rica. Livest. Prod. Sci. 75:101-116.

Veerkamp, R. F., P. Dillon, E. Kelly, A. R. Cromie, and A. F. Groen 2002. Dairy cattle breeding objectives combining yield survival and calving interval for pasture-based systems in Ireland under different milk quota scenarios. Livest. Prod. Sci. 76:137-151.

Veerkamp, R. F., G. C. Emmans, A. R. Cromie, and G. Simm. 1995. Variance components for residual feed intake in dairy cows. Livest. Prod. Sci. 41:111-120.
Vencl, B., Z. Frydrych, A. Krása, R. Pospíšil, J. Pozdíšek, A. Sommer M. Sime, and L. Zeman. 1991. Nové systémy hodnocení krmiv pro skot. Akademie zemědělskŷch věd ČSFR, Praha, Czech Republic.

Vérité, R., and J.-L. Peyraud. 1989. Protein: The PDI systems. Pages 33-47 in Ruminant Nutrition: Recommended Allowances and Feed Tables. R. Jarrige, ed. INRA, Paris, France.

Vermorel, R. 1989. Energy: The feed unit systems. Pages 23-32 in Ruminant Nutrition: Recommended Allowances and Feed Tables. R. Jarrige, ed. INRA, Paris, France.

Williams, Y. J., J. E. Pryce, C. Grainger, W. J. Wales, N. Linden, M. Porker, and B. J. Hayes. 2011. Variation in residual feed intake in Holstein-Friesian dairy heifers in southern Australia. J. Dairy Sci. 94:4715-4725.

Wolf, J., M. Wolfová, and E. Krupa. 2012. User's Manual for the Program Package ECOWEIGHT (C Programs for Calculating Economic Weights in Livestock), Version 5.3.2. Part 1: Programs EWBC (Version 2.3.1) and EWDC (Version 2.2.3) for Cattle. Praha-Uhř́něves, Institute of Animal Science, Prague, Czech Republic.

Wolfová, M., J. Přibyl, J. Wolf, and R. Zahrádková. 2006. Effect of subsidy regimes on economic values of functional traits in beef cattle breeding. J. Anim. Breed. Genet. 123:97-104.

Wolfová, M., J. Wolf, and J. Hyánek. 1995. Economic weights for beef production traits in the Czech Republic. Livest. Prod. Sci. 43:63-73.

Wolfová, M., J. Wolf, J. Kvapilík, and J. Kica. 2007a. Selection for profit in cattle. I. Economic weights for purebred dairy cattle in the Czech Republic. J. Dairy Sci. 90:2442-2455.

Wolfová, M., J. Wolf, J. Kvapilík, and J. Kica. 2007b. Selection for profit in cattle. II. Economic weights for dairy and beef sires in crossbreeding systems. J. Dairy Sci. 90:2456-2467.

Wolfová, M., J. Wolf, J. Přibyl, R. Zahrádková, and J. Kica. 2005a Breeding objectives for beef cattle used in different production systems: 1. Model development. Livest. Prod. Sci. 95:201-221.

Wolfová, M., J. Wolf, R. Zahrádková, J. Přibyl, J. Daňo, E. Krupa, and J. Kica. 2005b. Breeding objectives for beef cattle used in different production systems. 2. Model application to production systems with the Charolais breed. Livest. Prod. Sci. 95:217-230.

Yan, T., F. J. Gordon, R. E. Agnew, M. G. Porter, and D. C. Patterson. 1997. The metabolisable energy requirement for maintenance and the efficiency of utilisation of metabolisable energy for lactation by dairy cows offered grass silage-based diets. Livest. Prod. Sci. 51:141-150

Yan, T., C. S. Mayne, F. G. Gordon, M. G. Porter, R. E. Agnew, D. C. Patterson, C. P. Ferris, and D. J. Kilpatrick. 2010. Mitigation of enteric methane emissions through improving efficiency of energy utilization and productivity in lactating dairy cows. J. Dairy Sci. 93:2630-2638. 